\title{
Analisis Kemampuan Berpikir Kreatif Siswa dalam Menyelesaikan Soal Open Ended Bangun Ruang Sisi Datar
}

\author{
Dewi Nuur Rahmasari \\ dewi.rahmasari22@gmail.com
}

\begin{abstract}
Abstrak: Kreativitas merupakan salah satu hal yang penting dalam kehidupan. Kreativitas dapat dilihat dari tiga indikator kemampuan berpikir kreatif yaitu, kefasihan (fluency), fleksibilitas (flexibility), dan kebaruan (novelty). Tujuan penelitian ini adalah mendeskripsikan proses berpikir kreatif siswa SMP dalam menyelesaikan soal open ended bangun ruang sisi datar. Soal open ended dipilih karena dapat mendorong siswa berpikir kreatif. Subjek uji coba adalah 26 siswi kelas VIII D MTsN 1 Malang dengan kemampuan heterogen. Uji coba dilakukan pada siswa kelas VIII MTS Negeri 1 Malang yang telah menempuh materi bangun ruang sisi datar. Penelitian ini merupakan penelitian kualitatif deskriptif menggunakan instrumen tes berpikir kreatif dan wawancara untuk mengumpulkan data. Data berupa hasil tes kemampuan berpikir kreatif yang terdiri dari dua masalah dan wawancara. Selanjutnya data dianalisis berdasarkan tiga indikator kemampuan berpikir kreatif yaitu, kefasihan, fleksibilitas, dan kebaruan. Dari hasil analisis diketahui (1) pada indikator kefasihan, sebanyak $56,67 \%$ siswa menjawab soal dengan satu jawaban benar, sehingga kefasihan masih kurang ; (2) sebanyak $10 \%$ siswa menjawab soal dengan benar melalui satu cara, sehingga fleksibilitas masih kurang; (3) pada indikator kebaruan, tidak ada siswa yang menunjukkan kebaruan dalam mengerjakan soal. Berdasarkan hasil tersebut menunjukkan bahwa kemampuan berpikir kreatif siswa masih rendah Berdasarkan analisis hasil pengembangan diperoleh hasil bahwa LKS yang dikembangkan dinyatakan valid, praktis, dan efektif.
\end{abstract}

Kata Kunci: berpikir kreatif, kreativitas, open ended

\section{PENDAHULUAN}

Salah satu tujuan dari pendidikan adalah untuk mengembangkan potensi peserta didik agar menjadi manusia yang kreatif. Hal tersebut sesuai dengan undang-undang tentang Sistem Pendidikan Nasional RI Nomor 20 Tahun 2003 pasal 3. Nadjafikhah, dkk (2012) juga menyatakan bahwa salah satu tujuan dari sistem pendidikan harus mendidik agar orang menjadi kreatif. Berdasarkan pendapat di atas dapat disimpulkan bahwa tujuan pendidikan untuk menghasilkan siswa yang kreatif.

Berpikir kreatif merupakan suatu kegiatan mental yang digunakan seseorang untuk membangun suatu ide atau gagasan yang "baru" secara fasih dan fleksibel (Siswono,2008). Berbagai tahap akan dilalui dalam mewujudkan kreativitas. Tahapan dari berpikir kreatif yang paling berpengaruh dicetuskan oleh Wallas (Herring, dkk, 2009) yaitu persiapan, inkubasi, iluminasi, dan verifikasi. Berikut akan dijabarkan mengenai masing-masing tahapan dari berpikir kreatif menurut Soesilo (2014), yaitu 1) persiapan dicirikan dengan persiapan seseorang untuk memecahkan masalah dengan mengumpulkan data atau informasi. Kemudian data tersebut digunakan untuk memahami masalah, 2) Inkubasi, pada tahap ini pengumpulan informasi dihentikan, seseorang akan melepaskan diri untuk sementara dari masalah tersebut misalnya dengan beristirahat atau melakukan kegiatan lain, 3) Iluminasi, pada tahap ini merupakan tahap timbulnya insight (pemahaman yang mendalam), saat munculnya inspirasi atau gagasan baru untuk mengatasi masalah yang dihadapi, 4) Verifikasi, pada tahap ini dilakukan pengujian atau kreasi terhadap realitas. Jadi pada tahap verivikasi seseorang menguji atau meninjau kembali apakah idenya berhasil diterapkan 
Tiga indikator dari berpikir kreatif menurut Siswono (2008) yaitu (1) Fluency (kefasihan) dalam memecahkan masalah mengacu pada kemampuan siswa memberikan jawaban yang beragam dan benar dari masalah yang diberikan, (2) Flexibility (fleksibilitas) dalam memecahkan masalah mengacu pada kemampuan siswa dengan berbagai cara yang berbeda,(3) Novelty (kebaruan) dalam memecahkan masalah mengacu pada kemampuan siswa menjawab masalah dengan satu jawaban yang "tidak biasa" dilakukan oleh siswa pada tingkat pengetahuannya. Berikut adalah tingkatan berpikir kreatif siswa dalam pemecahan masalah.

1. Sangat Kreatif

Siswa mampu menunjukkan kefasihan, fleksibilitas, dan kebaruan dalam memecahkan masalah matematika.

2. Kreatif

Siswa mampu menunjukkan kebaruan dan kefasihan, atau fleksibilitas dan kefasihan dalam memecahkan masalah matematika.

3. Cukup Kreatif

Siswa mampu menunjukkan kebaruan atau fleksibilitas dalam memecahka masalah matematika

4. Kurang Kreatif

Siswa hanya mampu menunjukkan kefasihan saja dalam memecahka masalah matematika

5. Tidak Kreatif

Siswa tidak mampu menunjukkan ketiga indikator berpikir kreatif dalam memecahkan masalah matematika.

Kreativitas merupakan hasil dari berpikir kreatif. Berpikir divergen dianggap sebagai salah satu gambaran kreativitas matematika (Chamberlin dan Moon, 2005). Kemampuan berpikir divergen dapat dibangun melalui pembelajaran yang berorientasi pada pemecahan masalah open-ended (Suma, Sudiarta, Arnyana, \&Marhta, 2007). Menurut Simadha (1997) permasalahan terbuka (open-ended) adalah suatu permasalahan yang mempunyai banyak penyelesaian atau banyak cara untuk mendapatkan penyelesaian.

Salah satu materi matematika yang banyak digunakan dalam kehidupan sehari hari adalah kubus dan balok yang tercakup dalam materi bangun ruang sisi datar yang dipelajari pada kelas VIII SMP. Namun, sebagian besar siswa hanya mampu mengerjakan soal sebatas hafalan rumus. Banyak siswa yang merasa kesulitan ketika mengerjakan soal terbuka dan soal pemecahan masalah yang berkaitan dengan materi bangun ruang sisi datar (Setyani). Untuk mencapai tujuan pembelajaran tersebut secara maksimal, tidak hanya cukup dengan memberikan soal-soal tertutup (close-ended), tetapi juga juga pemberian soal-soal open-ended yang bisa mengembangkan pola pikir kreatif siswa (Mustikasari, Zulkardi \&Aisyah, 2010).

Pada penelitian ini soal yang digunakan sebagai tes untuk mengukur kemampuan berpikir kreatif siswa SMP adalah soal open ended pada materi bangun ruang sisi datar. Berikut soal yang digunakan dalam tes kemampuan berpikir kreatif siswa. 
1. Suatu miniatur gedung berbentuk seperti gambar dibawah ini. Hitunglah volume udara di dalam miniatur gedung dengan paling sedikit dua cara yang berbeda!

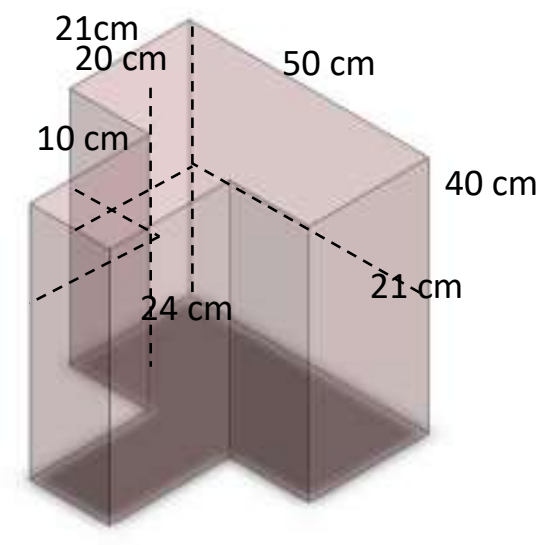

2. Gambar dibawah ini adalah gambar rancangan gedung yang akan dibangun. Permukaan gedung akan dibuat dari kaca (selain lantai dan atap). Tentukan kemungkinan-kemungkinan ukuran kaca dan banyak kaca yang digunakan untuk melapisi permukaan gedung (selain lantai dan atap).

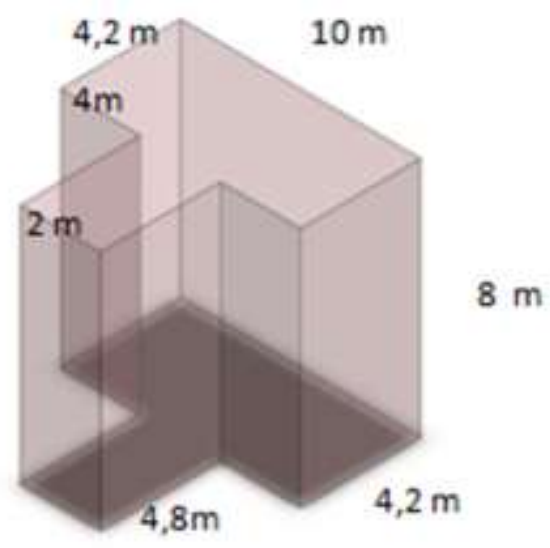

Penelitian ini bertujuan untuk mendeskripsıkan kemampuan berpikir kreatif siswa Kelas VIII MTsN 1 Malang pada materi bangun ruang sisi datar berdasarkan indikator kemampuan berpikir kreatif yaitu kefasihan, fleksibility, kebaruan. Dengan adanya penelitian ini, diharapkan dapat memberikan informasi dan gambaran kepada guru matematika tentang kondisi kemampuan berpikir kreatif siswa kelas VIII SMP, sehingga guru dapat merancang kegiatan pembelajaran yang dapat mengajak siswa untuk melatih kemampuan berpikir kreatif. 


\section{METODE}

- Penelitian ini menggunakan pendekatan kualitatif, dan bertujuan untuk menjabarkan kemampuan berpikir kreatif siswa. Jenis penelitian adalah penelitian deskriptif yakni, penelitian yang bertujuan untuk memberikan gambaran yang akurat atau karakteristik dari situasi atau fenomena. Penelitian ini dilakukan di MTsN 1 Malang. Subjek penelitian ini yaitu 26 siswa kelas VIII D

Prosedur penelitian ini yaitu tahap perancanaan, tahap penelitian, tahap analisis data. Kegiatan yang dilakukan tahap perencanaan adalah meminta izin kepada pihak sekolah dan menyusun instrumen penelitian. Kegiatan yang dilakukan pada tahap penelitian adalah memberikan tes kemampuan berpikir kreatif kepada siswa subjek uji coba. Sedangkan pada tahap analisis data kegiatan yang dilakukan adalah menganalisis hasil tes. Instrumen utama dalam penelitian ini adalah peneliti sendiri. Sedangkan instrumen pendukung adalah tes kemampuan berpikir kreatif. Tes kemampuan berpikir kreatif terdiri dari dua soal pada materi bangun ruang sisi datar. Pada soal nomor 1 siswa diminta untuk mencari volume udara dalam miniatur gedung yang terdapat pada gambar 1 . Kemudian setelah mendapatkan hasilnya, siswa dimita untuk menggunakan cara lain untuk menghitung volume udara dalam miniatur gedung tersebut. Melalui soal ini, peneliti ingin menilai kemampuan berpikir kreatif siswa dengan melihat seberapa banyak siswa menggunakan cara yang berbeda untuk menemukan jawaban yang benar (fleksibility). Pada soal nomor 2 siswa diminta untuk menentukan kemungkinan-kemungkinan ukuran kaca dan banyak kaca yang digunakan untuk melapisi permukaan gedung (selain lantai dan atap). Siswa diberi kebebasan untuk menentukan kemungkinan-kemungkinan ukuran kaca dan banyak kaca yang digunakan untuk melapisi permukaan gedung (selain lantai dan atap) sesuai dengan ukuran yang ada pada gambar. Dengan mengerjakan soal tersebut akan terlihat apakah siswa mampu menunjukkan kefasihan, fleksibilitas, atau kebaruan dalam mengerjakan soal open ended. Selanjutnya, peneliti melakukan wawancara dengan siswa untuk memperkuat data kemampuan berpikir kreatif siswa.

Data yang diperoleh kemudian dinilai dan diolah dengan menentukan persentase keterpenuhan masing-masing indikator. Persentase keterpenuhan setiap indikator kemampuan berpikir kritits berdasarkan rumus

keterangan:

$$
P_{i}=\frac{A_{i}}{n} \times 100 \%
$$

$P_{i}$ : persentase keterpenuhan indikator ke- $i$

$A_{i}$ : banyak siswa yang memenuhi indikator kemampuan berpikir kreatif ke- $i$

$n$ : banyak subjek uji coba.

\section{HASIL}

Tes kemampuan berpikir kreatif yang digunakan oleh peneliti untuk mengambil data terdiri dari dua masalah berkaitan dengan bangun ruang sisi datar. Soal tersebut diberikan kepada 26 siswa kelas VIII MTsN 1 Malang dengan waktu mengerjakan 60 menit. Hasil dari tes tersebut diperoleh data bahwa sebanyak 20 siswa atau 77\% memperoleh nilai diatas SKM yang ditetapkan yaitu 82 dan siswa minimal berada pada tingkat "Cukup Kreatif" dari tes yang diberikan. 
Tabel 1 Perolehan Nilai Tes Berpikir Kreatif

\begin{tabular}{|c|c|c|c|c|c|c|c|}
\hline No & Nama & $\begin{array}{c}\text { Skor } \\
\begin{array}{l}\text { Kefas } \\
\text { ihan }\end{array} \\
\end{array}$ & $\begin{array}{l}\text { Skor } \\
\text { Fleksibilitas }\end{array}$ & $\begin{array}{l}\text { Skor } \\
\text { Kebaruan }\end{array}$ & $\begin{array}{r}\text { Perolehan } \\
\text { Skor }\end{array}$ & $\begin{array}{l}\text { Nilai } \\
\text { TBK }\end{array}$ & $\begin{array}{c}\text { Tingkat } \\
\begin{array}{l}\text { Kreativ } \\
\text { itas }\end{array} \\
\end{array}$ \\
\hline 1. & ASA & 3 & 3 & 1 & 2,33 & 100 & Kreatif \\
\hline 2. & APA & 3 & 2 & 1 & 2 & 83 & Kreatif \\
\hline 3. & AWR & 2 & 2 & 1 & 1,67 & 67 & $\begin{array}{l}\text { Cukup } \\
\text { kreatif }\end{array}$ \\
\hline 4. & AA & 3 & 3 & 1 & 2,33 & 100 & Kreatif \\
\hline 5. & AR & 3 & 3 & 1 & 2,33 & 100 & Kreatif \\
\hline 6. & ADH & 3 & 2 & 1 & 2 & 83 & Kreatif \\
\hline 7. & AFB & 3 & 3 & 1 & 2,33 & 100 & Kreatif \\
\hline 8. & DP & 2 & 3 & 1 & 2 & 83 & Kreatif \\
\hline 9. & DMFS & 3 & 3 & 1 & 2,33 & 100 & Kreatif \\
\hline 10. & DAA & 1 & 3 & 1 & 1,67 & 67 & Cukup \\
\hline 11. & EYW & 2 & 2 & 1 & 1,67 & 83 & $\begin{array}{l}\text { Cukup } \\
\text { Kreatif }\end{array}$ \\
\hline 12. & FAIG & 2 & 2 & 1 & 1,67 & 67 & $\begin{array}{l}\text { Cukup } \\
\text { Kreatif }\end{array}$ \\
\hline 13. & F & 3 & 2 & 1 & 2 & 83 & Kreatif \\
\hline 14. & GAN & 3 & 3 & 2 & 2,67 & 100 & $\begin{array}{l}\text { Sangat } \\
\text { Kreatif } \\
\end{array}$ \\
\hline 15. & $\mathrm{H}$ & 3 & 2 & 1 & 2,33 & 83 & Kreatif \\
\hline 16. & MK & 2 & 2 & 1 & 1,67 & 83 & $\begin{array}{l}\text { Cukup } \\
\text { Kreatif }\end{array}$ \\
\hline 17. & MAR & 3 & 3 & 2 & 2,67 & 100 & Kreatif \\
\hline 18. & MAP & 3 & 3 & 0 & 2 & 100 & Kreatif \\
\hline 19. & NS & 1 & 3 & 1 & 1,67 & 83 & $\begin{array}{l}\text { Cukup } \\
\text { Kreatif }\end{array}$ \\
\hline 20. & NBD & 3 & 2 & 1 & 2 & 83 & Kreatif \\
\hline 21. & NEAK & 2 & 2 & 0 & 1,33 & 67 & $\begin{array}{l}\text { Cukup } \\
\text { Kreatif }\end{array}$ \\
\hline 22. & QRA & 3 & 2 & 1 & 2 & 83 & Kreatif \\
\hline 23. & RRA & 3 & 2 & 1 & 2,33 & 83 & Kreatif \\
\hline 24. & RM & 3 & 2 & 1 & 2 & 83 & Kreatif \\
\hline 25. & SHS & 2 & 3 & 2 & 2 & 83 & Kreatif \\
\hline 26. & ZME & 3 & 3 & 1 & 2,33 & 100 & Kreatif \\
\hline \multicolumn{5}{|c|}{ Total Skor yang Diperoleh } & 53,33 & 2247 & \multirow[t]{2}{*}{ Kreatif } \\
\hline \multicolumn{5}{|c|}{ Rata-rata Skor } & 2,05 & 85 & \\
\hline
\end{tabular}

Berdasarkan hasil tersebut dapat diketahui bahwa kemampuan siswa dalam berpikir kreatif yang meliputi kefasihan, fleksibilitas, dan kebaruan berada dalam katagori baik. 


\section{PEMBAHASAN}

Dari data pada Tabel 4.11, diperoleh hasil bahwa sebanyak 20 siswa atau $77 \%$ memperoleh nilai diatas SKM yang ditetapkan yaitu 82 dan siswa minimal berada pada tingkat "Cukup Kreatif" dari tes yang diberikan. Dengan demikian LKS dengan pendekatan open-ended yang dihasilkan dinyatakan efektif dan layak digunakan dalam pembelajaran.

Berikut adalah beberapa hasil pekerjaan siswa terkait tes berpikir kreatif.

1.

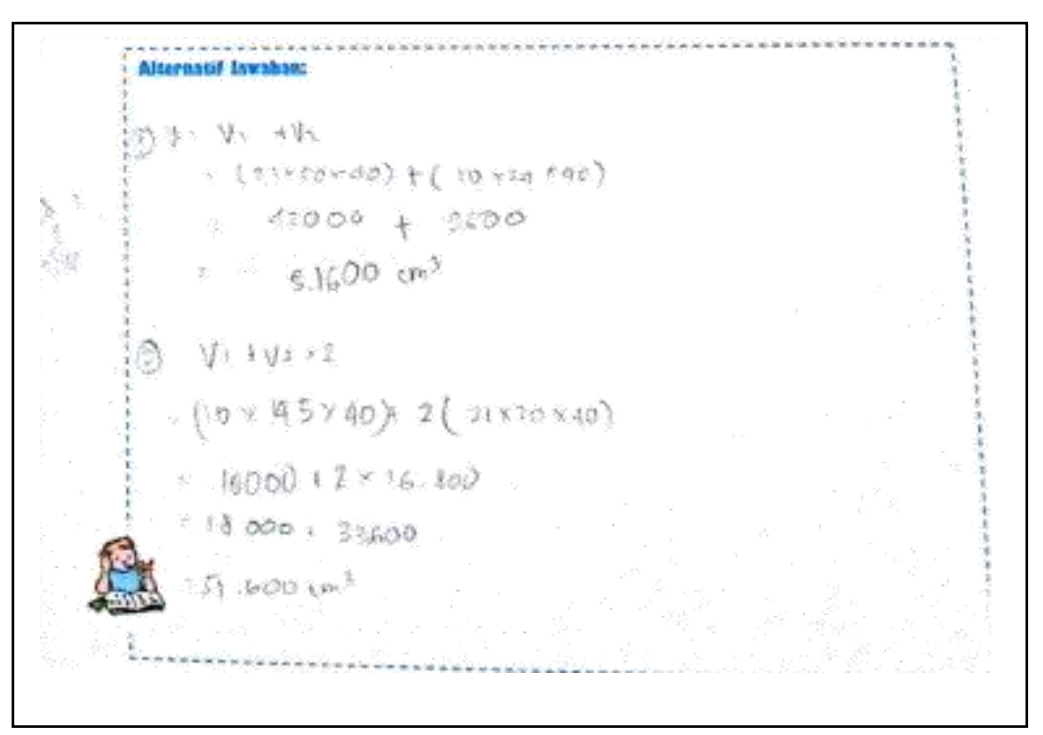

\section{Gambar Hasil Pekerjaan GAN Soal Nomor 1 Tes Berpikir Kreatif}

Hasil pekerjaan GAN menunjukkan bahwa ia telah memenuhi indikator fleksibilitas (flexibility). Hal ini dapat dilihat dari cara yang ia gunakan untuk menjawab soal tes berpikir kreatif nomor 1 GAN menggunakan dua cara berbeda dan menghasilkan jawaban yang benar. Selain itu GAN juga menunjukkan kefasihan (fluency) dan kebaruan (novelty) dalam menjawab soal tes berpikir kreatif nomor 2. GAN menggunakan cara yang tidak biasa dilakukan oleh teman-temannya untuk mencari kemungkinan-kemungkinan ukuran kaca dan banyak kaca yang digunakan untuk melapisi permukaan gedung (selain lantai dan atap) dengan mencari luas selubung bangun tersebut yaitu keliling alas dikali tinggi. GAN menemukan dua ukuran kaca yang digunakan untuk melapisi permukaan gedung (selain lantai dan atap) dengan cara luas selubung dibagi dengan luasukuran kaca yang ditentukan. 


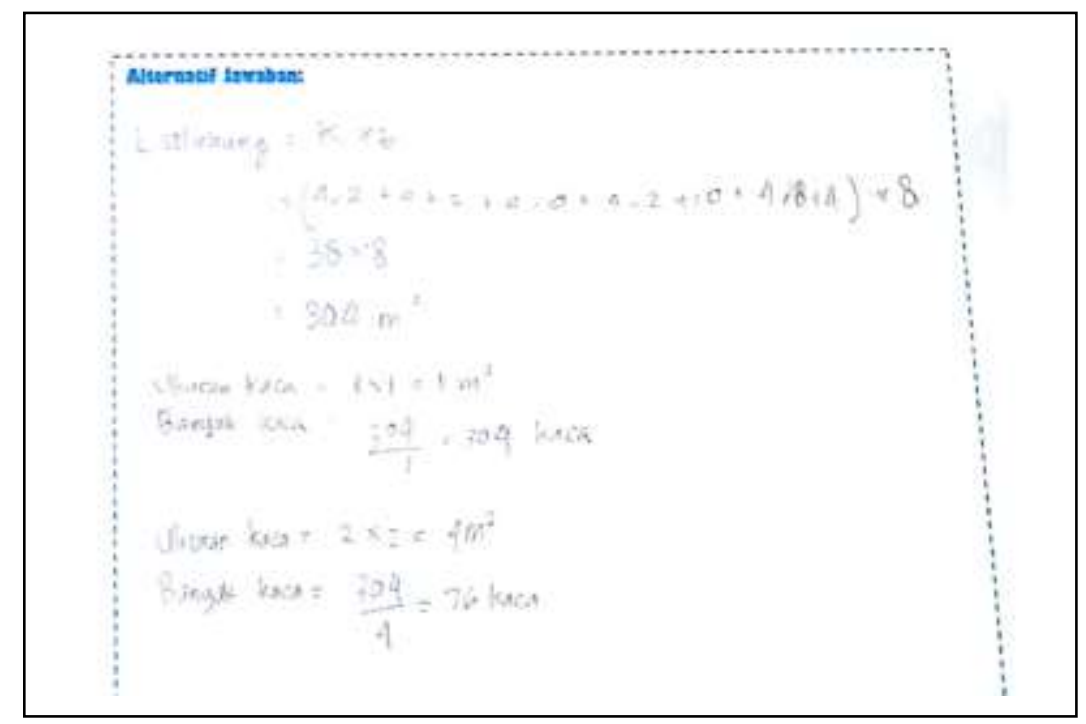

Gambar 4.7 Hasil Pekerjaan GAN Soal Nomor 2Tes Berpikir Kreatif

Oleh karena GAN mampu menunjukkan ketiga indikator berpikir kreatif yang meliputi kefasihan (fluency), fleksibilitas (flexibility), dan kebaruan (novelty), maka GAN berada pada tingkat 4 atau sangat kreatif berdasarkan tingkatan berpikir kreatif. Hal tersebut sesuai dengan pendapat Siswono (2008) yang menyatakan bahwa siswa yang berada pada tingkat 4 atau sangat kreatif ialah siswa yang mampu menunjukkan ketiga indikator berpikir kreatif yaitu kefasihan (fluency), fleksibilitas (flexibility), dan kebaruan (novelty).

2. Siswa dengan inisial NS mampu menunjukkan fleksibilitas dalam menjawab soal tes berpikir kreatif nomor 1. NS menggunakan dua cara berbeda dan menghasilkan jawaban yang benar. Hasil pekerjaan NS untuk soal nomor 1 tes berpikir kreatif dapat dilihat padagambar dibawah ini.
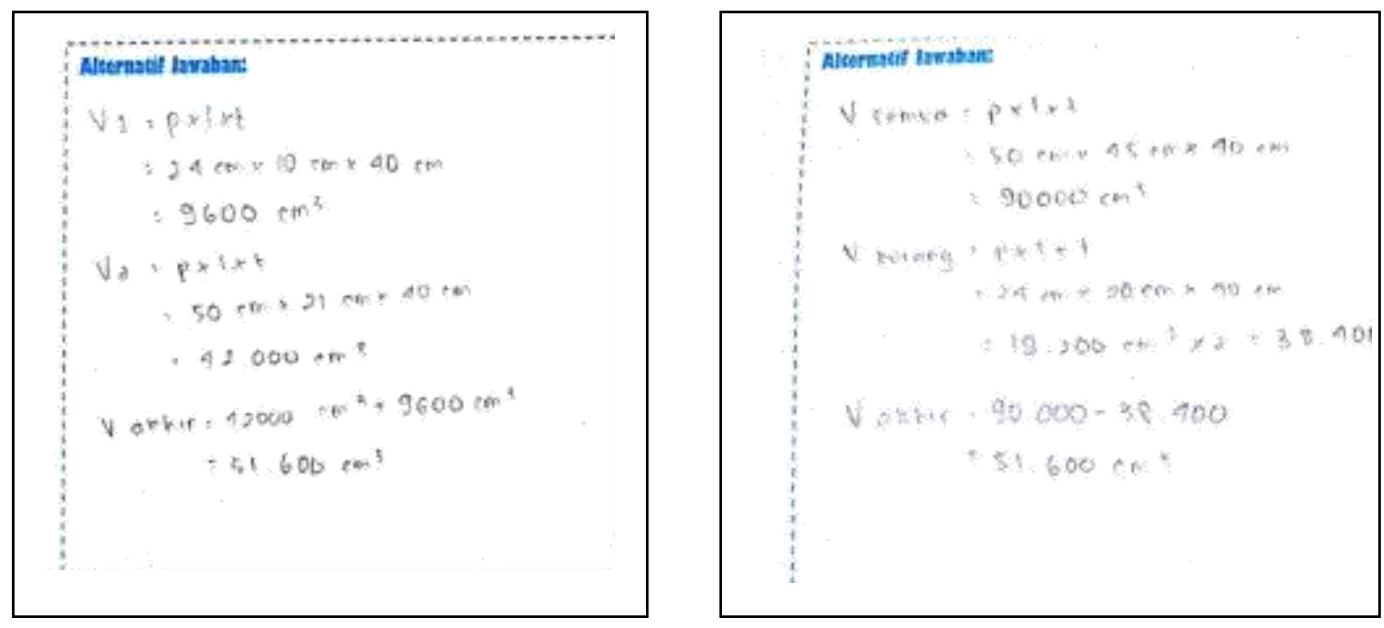

Gambar 4.8 Hasil Pekerjaan NS Soal Nomor 1 Tes Berpikir Kreatif

Untuk soal nomor 2 NS mencari kemungkinan-kemungkinan ukuran kaca dan banyak kaca yang digunakan untuk melapisi permukaan gedung (selain lantai dan atap) dengan mencari luas masing-masing sisi gedung (tanpa atap dan alas) kemudian luas masing-masing sisi tersbut dijumlahkan dan diperoleh luas $304 \mathrm{~m}^{2}$. Selanjutnya NS menentukan banyak kaca yang diperlukan ada 8 kaca dengan ukuran sesuai luas masing-masing sisi gedung. Karena NS hanya dapat menemukan 1 jawaban benar untuk soal nomor 2, maka skor kefasihan (fluency) yang ia peroleh adalah 1. Dalam menjawab soal tes berpikir kreatif yang diberikan, NS belum menunjukkan kebaruan (novelty), sehingga skor yang diperoleh untuk indikator kebaruan adalah 1. Hasil pekerjaan NS dapat dilihat pada gambar berikut. 


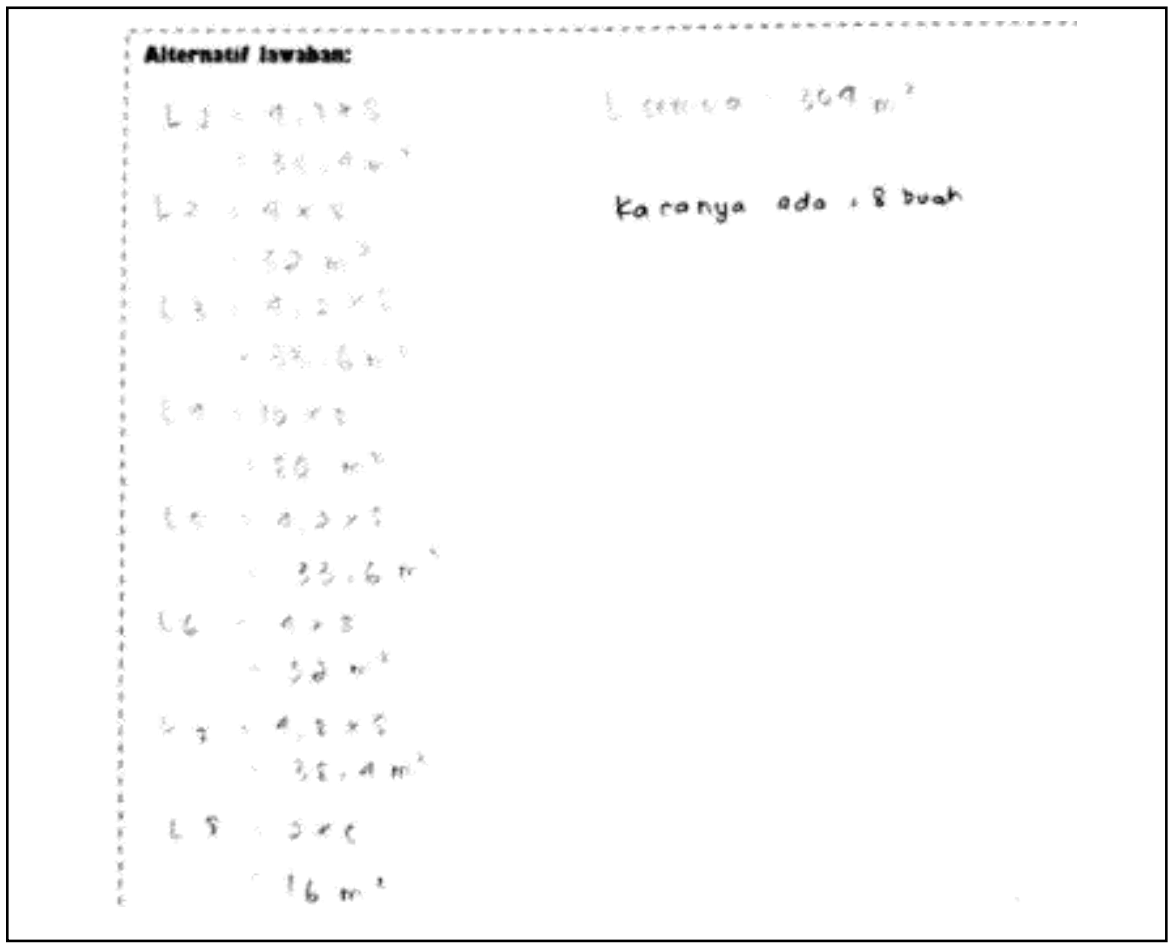

Gambar Hasil Pekerjaan NS Soal Nomor 1 Tes Berpikir Kreatif

Berdasarkan hasil analisis di atas diketahui NS hanya memenuhi indikator flesibilitas (flexibility) sehingga NS masuk dalam katagori cukup kreatif. Hal tersebut sesuai dengan pendapat Siswono (2008) yang menyatakan bahwa siswa yang berada pada tingkat 2 atau cukup kreatif ialah siswa yang mampu menunjukkan kebaruan (novelty) atau fleksibilitas (flexibility) dalam memecahkan masalah.

3. Siswa dengan inisial MAP mampu menunjukkan fleksibilitas dalam menjawab soal tes berpikir kreatif nomor 1. NS menggunakan dua cara berbeda dan menghasilkan jawaban yang benar. Hasil pekerjaan MAP untuk soal nomor 1 tes berpikir kreatif dapat dilihat pada gambar di bawah ini. 


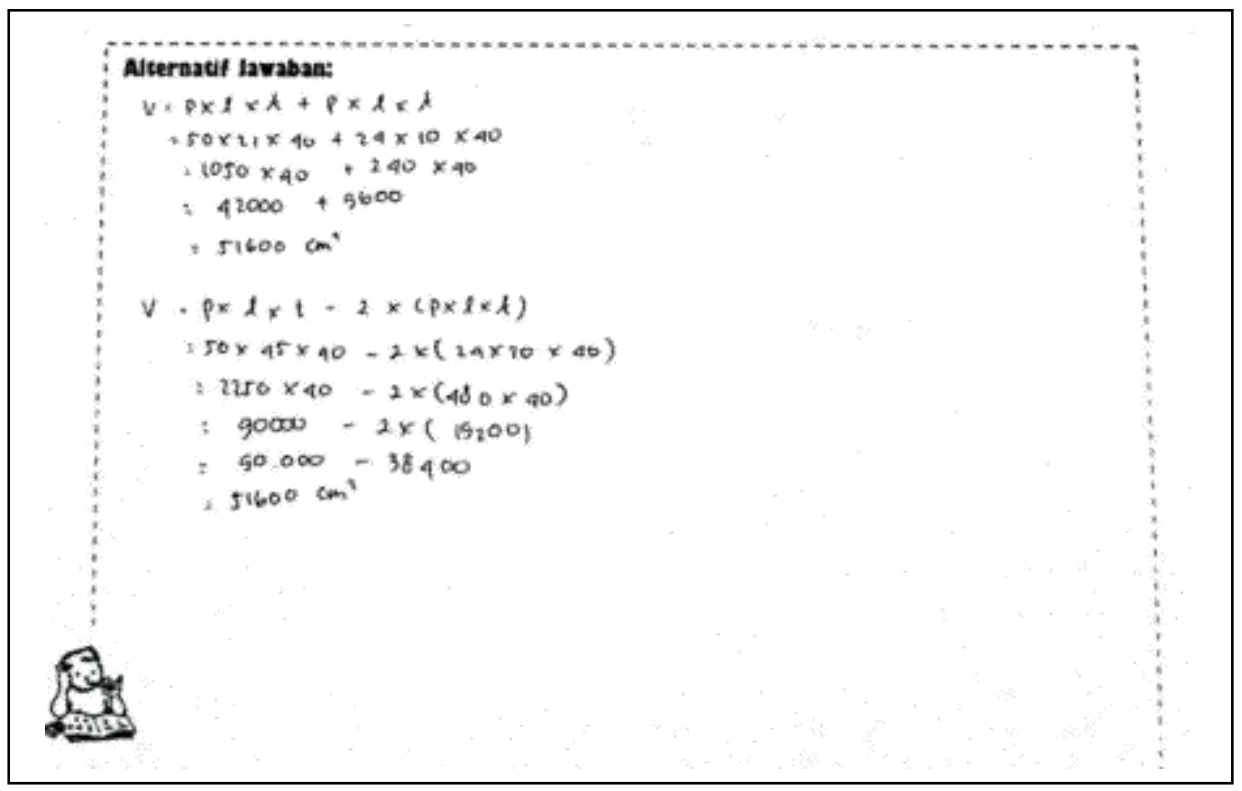

Gambar Hasil Pekerjaan MAP Soal Nomor 1 Tes Berpikir Kreatif

Untuk soal nomor 2 MAP mencari kemungkinan-kemungkinan ukuran kaca dan banyak kaca yang digunakan untuk melapisi permukaan gedung (selain lantai dan atap) dengan mencari luas masing-masing sisi gedung (tanpa atap dan alas) kemudian luas masing-masing sisi tersbut dijumlahkan dan diperoleh luas $304 \mathrm{~m}^{2}$. Selanjutnya MAP menentukan banyak kaca yang diperlukan ada 31 kaca yang diperoleh dari luas permukaan dibagi dengan luas ukuran kaca (304 $\mathrm{m}^{2}$ ) yang ditentukan $\left(10 \mathrm{~m}^{2}\right)$ diperoleh 30,4 kaca dibulatkan menjadi 31 kaca. Kemudian MAP menentukan banyak kaca yang diperlukan ada 16 kaca yang diperoleh dari luas permukaan dibagi dengan luas ukuran kaca $\left(304 \mathrm{~m}^{2}\right)$ yang ditentukan $\left(20 \mathrm{~m}^{2}\right)$ diperoleh 15,2 kaca dibulatkan menjadi 16 kaca. Hasil pekerjaan NS dapat dilihat pada gambar berikut. 


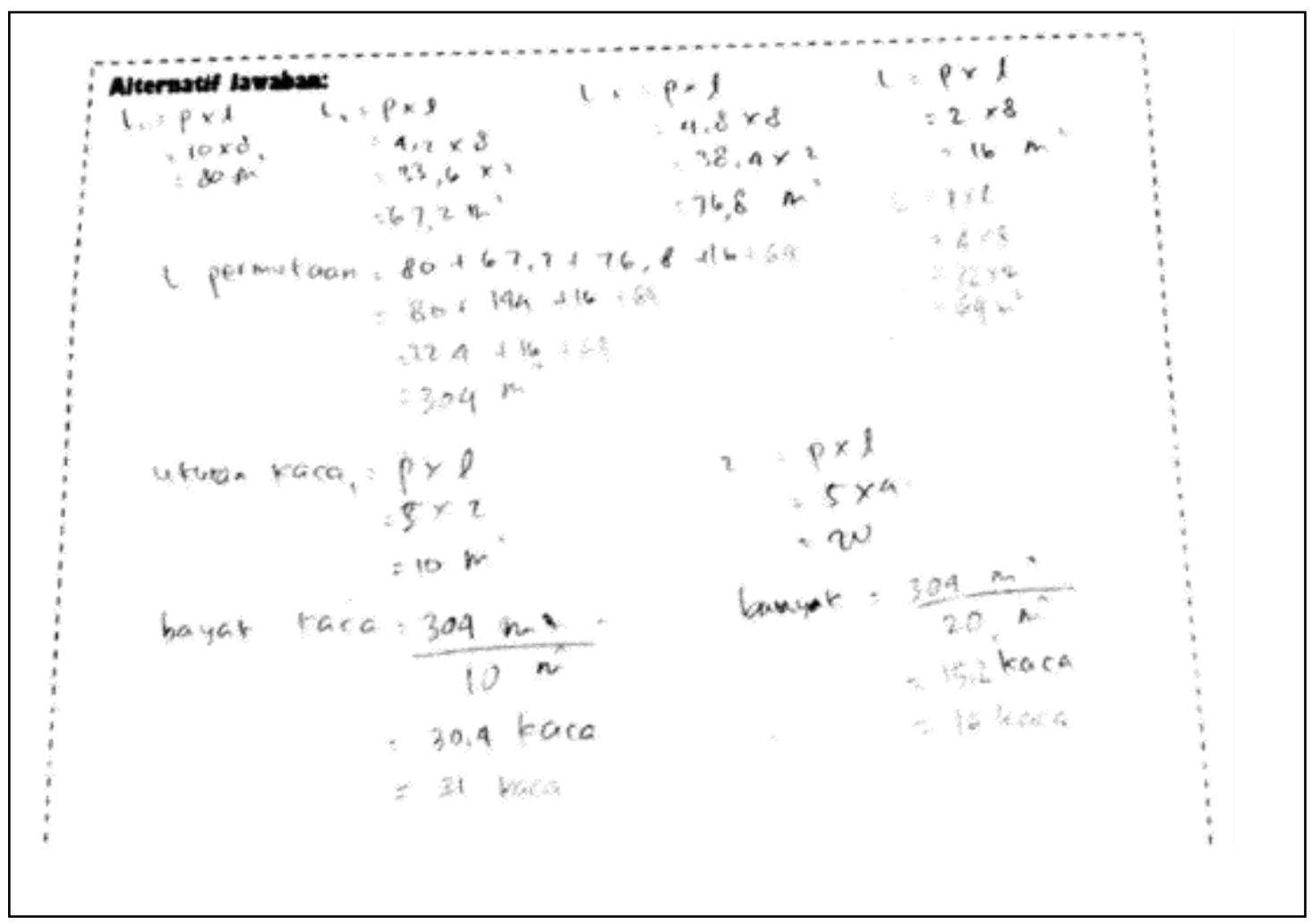

Gambar Hasil Pekerjaan MAP Soal Nomor 1 Tes Berpikir Kreatif

Berdasarkan hasil analisis di atas diketahui NS hanya memenuhi indikator flesibilitas (flexibility) dan kefasihan (fluency) sehingga MAP masuk dalam katagori kreatif. Hal tersebut sesuai dengan pendapat Siswono (2008) yang menyatakan bahwa siswa yang berada pada tingkat 3 atau kreatif ialah siswa yang mampu menunjukkan kebaruan dan kefasihan, atau fleksibilitas dan kefasihan dalam memecahkan masalah matematika.

\section{PENUTUP}

\section{Kesimpulan}

Berdasarkan hasil analisis data dapat disimpulkan bahwa kemampuan berpikir kreatif siswa SMP kelas VIII masih tergolong baik berdasarkan indikator, sebagian besar siswa mampu menunjukkan berpikir kreatif yaitu kefasihan, fleksibilitas dan kebaruan dalam mengerjakan soal.

Hasil penelitian ini memberikan gambaran kepada guru dan para peneliti tentang kondisi kemampuan berpikir kreatif siswa SMP kelas VIII. Dengan mengetahui kondisi seperti ini, guru dan para peneliti diharapkan dapat merancang dan mengembangkan pembelajaran yang mampu memfasilitasi siswa untuk berpikir kreatif, dan membiasakan siswa untuk berpikir kreatif.

\section{Saran}

Saran bagi peneliti lain yang akan melakukan penelitian seperti penelitian ini untuk memvalidasi tes yang akan diberikan kepada siswa, sehingga isi permasalahan menjadi lebih baik. Berkaitan dengan validasi pada aspek kebahasaan, sebaiknya validator adalah seorang ahli bahasa,sehingga dapat diketahui dengan pasti bahasa yang digunakan sesuai dengan kaidah Bahasa 
Indonesia yang benar,efektif, efisien, jelas, mudah dipahami, serta tidak menimbulkan makna ganda. Sedangkan saran untuk guru adalah sebaiknya merancang pembelajaran atau bahan ajar yang dapat melatih siswa untuk berpikir kreatif, melalui aktivitas-aktitas dan strategi pembelajaran.

\section{DAFTAR PUSTAKA}

Anwar, M.N., Aness, M., Khizar, A., Naseer, M. \& Muhammad, G. 2012. Relationship of Creative Thinking with the Academic Achievements of Secondary School Students. International Interdisciplinary Journal of Education - April 2012, Volume 1, Issue 3

As'ari, A.R. 2016. Pembelajaran Matematika Untuk Meningkatkan Kreativitas Matematis Dan Penelitian Matematis. Makalah dalam Seminar Nasional di Universitas Negeri Malang 2016

Depdiknas. 2008. Panduan Pengembangan Bahan Ajar. Jakarta: Depdiknas.

Herring, S. R, Jones, B.R., Bailey, B.P. 2009. Idea Generation Techniques among Creative Professionals. Proceedings of the 42nd Hawaii International Conference on System Sciences 2009

Hobri. 2010. Metodologi Penelitian Pengembangan (Aplikasi pada Penelitian Pendidikan Matematika). Jember: Pena Salsabila.

Kemendikbud. 2014. Materi Pelatihan Guru Implementasi Kurikulum 2013 Tahun 2014. Jakarta: Badan Pengembangan Sumber Daya Manusia Pendidikan dan Kebudayaan dan Penjaminan Mutu Pendidikan Kementerian Pendidikan dan Kebudayaan .

Lin, Y. 2011. Fostering Creativity through Education-A Conceptual Framework of Creative Pedagogy. Creative Education 2011. Vol.2, No.3, 149-155

Muhsetyo, G. 2016. Mengembangkan Masalah Sederhana Mencari Luas Banbgun Datar Menjadi Masalah Open-Ended Konseptual yang Menantang. https://www.researchgate.net/publication/301548630_MENGEMBANGKAN_MASALAH_SE DERHANA_MENCARI_LUAS_BANBGUN_DATAR_MENJADI_MASALAH_OPENEND ED_KONSEPTUAL_YANG_MENANTANG. (online). diakses pada 15 Maret 2017

Mustikasari, Zulkardi, Aisyah, N.. 2010. Pengembangan Soal-Soal Open-Ended Pokok Bahasan Bilangan Pecahan di Sekolah Menengan Pertama. Jurnal Pendidikan Matematika, Volume 4. No.1, Juli 2010

Nadjafikhah, M., Yaftian, N., Bakhshalizadeh, S. 2012. Mathematical creativity: some definitions and characteristics. Procedia - Social and Behavioral Sciences 31 (2012) 285 - 291

Plomp,T. 2010. Educational Design Research: An Introduction. Dalam Tjeer Plomp and Nienke Nieeveen (Ed). An introduction to Educational Design Research. (p:9-35). (Online), (Netherlands in www.slo.nl/organisatie/international/publications), diakses pada 5 Mei 2017. 
Setyani. Mengembangkan Kemampuan Berpikir Kreatif Siswa Melalui Pembelajaran Topik Bangun Ruang Sisi Datar.(online). (https://www.academia.edu/5504318/ Mengembangkan_Kemampuan_Berpikir_Kreatif_Siswa_Melalui_Pembelajaran_Topik_Bangun_ Ruang_Sisi_Datar), diakses 24 Febrari 2017.

Shimada, S. 1997. The Significance of an Open-Ended Approach. Dalam J.P. Becker \& S. Shimada (Eds), The Open Ended Approach: A New Proposal for Teaching Mathematics. Reston: The National Council of Teachers of Mathematics, Inc.

Siswono, T.Y.E. 2008. Proses Berpikir Kreatif Siswa dalam Memecahkan dan Mengajukan Masalah Matematika. Jurnal Ilmu Pendidikan, Jilid 15, Nomor 1, Februari 2008, hlm. 60-68

Soesilo, T.D. 2014. Pengembangan Kreativitas Melalui Pembelajaran. Yogyakarta: Penerbit Ombak.

Suma, K., Sudiarta, I.G.P., Arnyana, I.B.P., Marhta, I.N. 2007. Pengembangan Keterampilan Berpikir Divergen Melalui Pemecahan Masalah Matematika-Sains Terpadu Open-Ended Argumentatif. Jurnal Pendidikan dan Pengajaran Undiksha, No. 4 Th. XXXX Oktober 2007

Undang-Undang RI No. 20 Tahun 2003 tentang Sistem Pendidikan Nasional. 2010. Bandung: PT Fokusmedia

Wessels, H. 2014. Levels of mathematical creativity in model-eliciting activities. Journal of Mathematical Modelling and Application. Vol. 1, No. 9, 22-40

Wijaya, A. 2012. Pendidikan Matematika Realistik: Suatu Alternatif Pendekatan Pembelajaran Matematika. Yogyakarta: Graha Ilmu. 